\title{
Influence of Garden Cress Seed (Lepidium sativum L.) Bran on Quality Characteristics of Cookies
}

\author{
Y.R. Deshmukh*, S.S. Thorat and S.R. Mhalaskar \\ Department of Food Science and Technology, Post Graduate Institute, Mahatma Phule Krishi \\ Vidyapeeth, Rahuri. Tal., Rahuri Dist., Ahmednagar, Maharashtra-413 722, India \\ *Corresponding author
}

\section{A B S T R A C T}

\begin{tabular}{|l|}
\hline K e y w o r d s \\
$\begin{array}{l}\text { Cookies, Dietary } \\
\text { fiber, Garden cress } \\
\text { seed, Sensory } \\
\text { evaluationetc. }\end{array}$ \\
\hline Article Info \\
\hline $\begin{array}{l}\text { Accepted: } \\
\text { 04 July 2017 } \\
\text { Available Online: } \\
\text { 10 September } 2017\end{array}$ \\
\hline
\end{tabular}

Garden cress (GC) is a fast-growing edible plant. Seeds, leaves and roots of GC are of economic importance, however, the crop is mainly cultivated for seeds. GC seeds have been used in traditional medicine since ancient times in India. Despite of its great medicinal value, $L$. sativum has not received the attention it deserves and has remained an under-utilized crop altogether. In present study efforts were made to separate bran from seed and its chemical composition was determined. The possibility of using it as nutraceutical food ingredient in cookies formulation was explored. Results revealed that GC seed bran contains $5.32 \%$ moisture, $13.61 \%$ protein, $52.05 \%$ carbohydrates, $7.29 \%$ fat, $5.60 \%$ ash, $16.13 \%$ crude fiber and $74.22 \%$ dietary fiber. Mineral composition (mg per $100 \mathrm{~g}$ ) of GC bran such as calcium, phosphorous, iron and zinc was 623.11, 182.09, 5.96 and 2.69. 05, 10, 15 and $20 \%$ GC seed bran were incorporated in cookies formulation on $100 \mathrm{~g}$ flour basis. Sensory analysis revealed highest overall acceptability for sample containing $10 \%$ GC seed bran. Addition of GC seed bran showed significant increase in dietary fiber and minerals content of cookies. It was concluded that GC seed bran fortification can improve nutritional and functional characteristics of cookies.

\section{Introduction}

Garden cress (Lepidium sativum L.) is a member of the mustard family Cruciferae(Brassicaceae).The most commonly cultivated cress variety is garden cress or peppergrass (Kiple and Kriemhild, 2000). Garden Cress (GC) is also known as "Halim" in urdu, Halive in marathi or Chandrasur in local languages. The $\mathrm{GC}$ or land cress is grown worldwide and is used at the cotyledon or seedling stage as a salad component (Mabberley, 1993). In India, it is mainly cultivated in U.P., Rajasthan, Gujarat, Maharashtra, and Madhya Pradesh (The Wealth of India, 1962).
GC has been considered as an important medicinal plant since the vedic era. It has been used for the treatment and/or prevention of bronchial asthma, breast cancer, hypercholestermia, Osteoarthritis, inflammation, rheumatism and muscular pain, diarrhea, migraine, cough, scurvy and seminal weakness and bleeding piles.

It is rich in proteins, vitamins, minerals, especially calcium and iron. GC seeds contain $24 \%$ fat in which $34.5 \%$ of total fatty acids is $\alpha$-linolenic acid (ALA, 18:3) (Bryan et al., 2009). The seeds are rich phenolic 
compounds and have high antioxidant activity compared to other cress varieties. It contains many phytochemicals with potential nutraceutical activity like glucosinolates, flavonoids, coumarins, sulphur glycosides, triterpenes, sterols and various imidazole alkaloids (Gill and Macleod, 1980; Maier et al., 1998).

Despite of its high medicinal value and widespread traditional uses of $\mathrm{GC}$, there are very few studies reported for its utilization in processed foods. The present investigation was initiated to explore the possibility of incorporating GC seed bran in bakery product. This study is aims to improve market value of GC by its utilization in value added products, as well as to provide highly sought after nutraceuticals in convenient form to the health conscious consumers.

\section{Materials and Methods}

\section{Bakery ingredients}

GC seeds, bakery shortening fat, wheat flour and sugar powder were purchased from a local market. The garden cress seeds were air dried, passed through a Brabender flour mill.

The separated bran was collected and used in cookies formulation.

\section{Chemicals}

Food-grade quality sodium bicarbonate and ammonium bicarbonate were used in cookies preparations. All chemicals were procured from Himedia Laboratories, Mumbai, India.

\section{Preparation of cookies}

The refined wheat flour $(100 \mathrm{~g})$, salt $(2.5 \mathrm{~g})$ and baking powder $(1.0 \mathrm{~g})$ were thoroughly mixed and sieved twice for uniform blend. Shortening (50 g) and ground sugar (50 g) were creamed together manually for $10 \mathrm{~min}$. to get bright and fluffy mass. Finally, dry ingredient blend flour including GC seed bran incorporated flour by replacing wheat flour at $5 \%, 10 \%$ and $15 \%$ and $20 \%$ level was slowly added to creamed mass and mixed for 2 min. The dough was sheeted to $8 \mathrm{~mm}$ thickness and cut into circular shape using 42 $\mathrm{mm}$ diameter cutter. The cookies were then baked at $180{ }^{\circ} \mathrm{C}$ for $15 \mathrm{~min}$ and cooled for 10 min, wrapped in aluminium foil and packed in polyethylene bag.

\section{Physicochemical qualities of cookies}

\section{Physical qualities of cookies}

The diameter of the cookies was measured by laying four cookies edge-to-edge with the help of a scale. The same set of cookies was rotated $90^{\circ} \mathrm{C}$ and the diameter was remeasured. Average values of these cookies are reported in $\mathrm{cm}$. The thickness (T) of cookies was measured by stacking four cookies on top of one another and taking their average in $\mathrm{mm}$. The spread ratio was calculated by dividing the diameter (D) by thickness (T) Rangrej et al., (2015).

\section{Proximate and minerals composition of} maida, GC seed bran and prepared cookies

The moisture, fat, protein, crude fiber, dietary fiber and ash content of the maida, GC seed bran and prepared cookies were determined according to the AOAC official methods (AOAC, 1990). Carbohydrates were calculated by difference method.

\section{Sensory qualities of cookies}

The cookies were evaluated for sensory attributes like colour, flavour, texture, taste and overall acceptability by a panel of 10 semi-trained judges, using a 9 point Hedonic scale system (Amerine et al., 1965). 


\section{Statistical analysis}

The data obtained was analyzed statistically using Completely Randomized Design (CRD) used to test the significance of results (Panse and Sukhatme, 1985). The analysis of variance was performed at significance of $p<0.05$ level, S.E. and C.D. at $5 \%$ level was mentioned wherever required.

\section{Results and Discussion}

\section{Proximate composition of wheat flour and garden cress seed bran}

The whole cress seed had 76.12 per cent endosperm and 23.88 per cent bran (Table 1). The moisture, carbohydrate, protein, fat, crude fiber, dietary fiber and ash content of wheat flour was $13.89,71.02,12.22,1.76$, $0.67,0.36$ and 1.11 per cent, respectively whereas the proximate composition of garden cress seed bran shows 5.32 per cent moisture, 52.05 per cent carbohydrate, 13.61 per cent protein, 7.29 per cent fat, 16.13 per cent crude fiber, 74.22 per cent dietary fiber and 5.60 per cent ash.

Gokavi et al., (2004) reported that GC seed had 72 per cent endosperm and 28 per cent bran. The whole meal, endosperm and bran of garden cress seed had 4.14, 2.28 and 4.27 per cent moisture, 22.5, 27.7 and 12.6 per cent protein, 27.5, 33.1 and 6 per cent fat, 34.24, 28.45 and 50.31 per cent carbohydrates, 7.01, 4.00 and 14.29 per cent crude fiber, 30, 13.6 and 75 per cent dietary fiber and 4.65, 4.06 and 6.19 per cent ash, respectively.

\section{Mineral content of wheat flour and garden cress seed bran}

Calcium content of maida was $38.22 \mathrm{mg} / 100 \mathrm{~g}$ (Table 2). It contained $119.13 \mathrm{mg} / 100 \mathrm{~g}$ phosphorus. The iron and zinc content of maida was 4.12 and $0.82 \mathrm{mg} / 100 \mathrm{~g}$. Similar results were observed by Desai et al., (2010);
Kulkarni et al., (2012) and Singh et al., (2005).

GC seed bran contains $623.11 \mathrm{mg}$ of calcium, $182.09 \mathrm{mg}$ of phosphorous, $5.96 \mathrm{mg}$ of iron and $2.69 \mathrm{mg} / 100 \mathrm{~g}$ zinc. Gokavi et al., (2004) reported the whole meal, endosperm and bran of GC seed had 296.60, 210.51 and $556.32 \mathrm{mg}$ calcium, 514.59, 652.81 and $209.92 \mathrm{mg}$ phosphorous, $7.62,8.31$ and 6.61 $\mathrm{mg}$ iron and 5.05, 5.31 and $2.98 \mathrm{mg}$ zinc, respectively.

\section{Influence of garden cress seed branon physical quality of cookies}

In order to understand the significance of GC seed bran addition on physical properties such as weight, diameter, thickness, spread ratio and spread factor were determined. The treatment $\mathrm{GCB}_{20}$ obtained highest weight $(10.19 \mathrm{~g})$ after baking and lowest $(10.02 \mathrm{~g})$ in treatment $\mathrm{GCB}_{0}$ (Table 3). The thickness for treatment $\mathrm{GCB}_{0}(13.73 \mathrm{~mm})$ was highest among all other treatments. The treatment $\mathrm{GCB}_{5}$ exhibited lowest thickness of cookies $(10.28 \mathrm{~mm})$. The treatment $\mathrm{GCB}_{5}$ was statistically superior in spread ratio (4.47) of cookies after baking over all other treatments. Treatment $\mathrm{GCB}_{5}$ shows highest spread factor (133.43) after baking. The changes in diameter and thickness are reflected in spread ratio which decreased consistently and adversely affecting the thickness and diameter and thus, spread ratio of the supplemented biscuits (Eissa et al., 2007).

Reduced spread ratio of cookie was attributed to the fact that composite flours apparently form aggregates with increased numbers of hydrophilic sites available for competing for the limited free water in cookie dough (Hooda and Jood, 2005). Rapid partitioning of free water of these hydrophilic sites occurs during dough mixing and increases dough viscosity, thereby limiting cookie spread and top grain formation during baking. 
Influence of garden cress seed bran on sensory quality of cookies

The changes in the sensory characteristics like colour and appearance, texture, flavour, taste, and overall acceptability were statistically significant among all the treatments (Table 4). The cookies sample prepared with the treatment $\mathrm{GCB}_{10}$ was statistically superior for overall acceptability over all other treatments.

The cookies prepared with treatment $\mathrm{GCB}_{20}$ obtained lowest score for overall acceptability. The score was decreased for colour and appearance from 8.12 in control $\left(\mathrm{GCB}_{0}\right)$ to $6.12 \mathrm{GCB}_{20}$, texture 8.00 in control to $6.62 \mathrm{GCB}_{20}$, flavour 7.87 in control to 6.50
$\mathrm{GCB}_{20}$, taste 8.0 in control to $6.00 \mathrm{GCB}_{20}$, respectively. Overall acceptability of garden cress seed bran incorporated cookies was higher (7.93) in $\mathrm{GCB}_{10}$ than control (7.87).The colour score of cookies obtained with use of garden cress seed bran was less acceptable as compared to control. This may be due to brownish colour of the bran and at $20 \%$ level of bran, the darker colour was prevalent.It was revealed that, $10 \%$ addition of bran helped in improved acceptability of cookies. The soft texture and pleasant flavour in cookies was achieved with addition of $10 \%$ bran. Cookies containing up to $20 \%$ wheat bran were acceptable to a consumer panel (Vratanina and Zabik, 1978) and 30\% use of oat bran (Sudha et al., 2007).

Table.1 Proximate composition of maida and garden cress seed bran

\begin{tabular}{|c|l|c|c|}
\hline Sr. No. & \multicolumn{1}{|c|}{ Parameter (\%) } & Maida & Garden cress seed Bran \\
\hline $\mathbf{1}$ & Moisture & 13.89 & 5.32 \\
\hline $\mathbf{2}$ & Protein & 12.22 & 13.61 \\
\hline $\mathbf{3}$ & Fat & 1.76 & 7.29 \\
\hline $\mathbf{4}$ & Carbohydrate & 71.02 & 52.05 \\
\hline $\mathbf{5}$ & Crude fibre & 0.67 & 16.13 \\
\hline $\mathbf{5}$ & Dietary fiber & 0.36 & 74.22 \\
\hline $\mathbf{6}$ & Ash & 1.11 & 5.60 \\
\hline
\end{tabular}

* Each value represents the average of five determinations

Table.2 Minerals composition of different fractions of garden cress seed

\begin{tabular}{|c|l|c|c|}
\hline Sr. No. & Parameter (mg per 100 g) & Maida & Garden cress seed Bran \\
\hline $\mathbf{1}$ & Calcium & 38.22 & 623.11 \\
\hline $\mathbf{2}$ & Phosphorous & 119.13 & 182.09 \\
\hline $\mathbf{3}$ & Iron & 4.12 & 5.96 \\
\hline $\mathbf{4}$ & Zinc & 0.82 & 2.69 \\
\hline
\end{tabular}

Table.3 Influence of garden cress seed bran on physical quality of cookies

\begin{tabular}{|l|c|c|c|c|c|}
\hline Attributes & $\begin{array}{c}\text { Weight } \\
\mathbf{( g})\end{array}$ & $\begin{array}{c}\text { Diameter } \\
(\mathbf{m m})\end{array}$ & $\begin{array}{c}\text { Thickness } \\
(\mathbf{m m})\end{array}$ & $\begin{array}{c}\text { Spread } \\
\text { ratio }\end{array}$ & Spread factor (\%) \\
\hline Treatments & 10.02 & 46.11 & 13.73 & 3.35 & 100 \\
\hline $\mathrm{Control}$ & 10.11 & 46.03 & 10.28 & 4.47 & 133.43 \\
\hline $\mathrm{GCB}_{5}$ & 10.14 & 45.33 & 11.05 & 4.10 & 122.38 \\
\hline $\mathbf{G C B}_{10}$ & 10.19 & 45.11 & 12.58 & 3.58 & 106.86 \\
\hline $\mathrm{GCB}_{15}$ & 10.25 & 44.47 & 13.48 & 3.29 & 98.20 \\
\hline $\mathrm{GCB}_{20}$ & 0.016 & 0.013 & 0.011 & 0.039 & 0.19 \\
\hline $\mathrm{SE} \pm$ & 0.05 & 0.03 & 0.03 & 0.11 & 0.58 \\
\hline $\mathrm{CD}$ at $5 \%$ &
\end{tabular}

Where, $\mathrm{GCB}_{5}=5 \%$ bran, $\mathrm{GCB}_{10}=10 \%$ bran, $\mathrm{GCB}_{15}=15 \%$ bran and $\mathrm{GCB}_{20}=20 \%$ bran 
Table.4 Influence of garden cress seed bran on sensory quality of cookies

\begin{tabular}{|l|c|c|c|c|c|}
\hline Attributes & Colour & Texture & Flavour & Taste & $\begin{array}{c}\text { Overall } \\
\text { Acceptability }\end{array}$ \\
\cline { 1 - 5 } Treatments & 8.12 & 8.00 & 7.87 & 8.00 & 7.87 \\
\hline Control & 7.37 & 7.5 & 7.31 & 7.31 & 7.56 \\
\hline $\mathrm{GCB}_{5}$ & $\mathbf{7 . 2 5}$ & $\mathbf{7 . 9 3}$ & $\mathbf{7 . 7 5}$ & $\mathbf{7 . 8 7}$ & $\mathbf{7 . 9 3}$ \\
\hline $\mathbf{G C B}_{10}$ & 6.87 & 7.00 & 7.12 & 6.62 & 6.75 \\
\hline $\mathrm{GCB}_{15}$ & 6.12 & 6.62 & 6.5 & 6.00 & 6.12 \\
\hline $\mathrm{GCB}_{20}$ & 0.07 & 0.04 & 0.02 & 0.05 & 0.008 \\
\hline $\mathrm{SE} \pm$ & 0.022 & 0.12 & 0.07 & 0.15 & 0.02 \\
\hline $\mathrm{CD}$ at $5 \%$ & &
\end{tabular}

Where, $\mathrm{GCB}_{5}=5 \%$ bran, $\mathrm{GCB}_{10}=10 \%$ bran, $\mathrm{GCB}_{15}=15 \%$ bran and $\mathrm{GCB}_{20}=20 \%$ bran

Table.5 Influence of garden cress seed bran on proximate composition of cookies

\begin{tabular}{|l|c|c|c|l|l|l|l|}
\hline Treatments & $\begin{array}{c}\text { Moisture } \\
(\boldsymbol{\%})\end{array}$ & $\begin{array}{c}\text { Protein } \\
(\boldsymbol{\%})\end{array}$ & $\begin{array}{c}\text { Carbohydrate } \\
(\boldsymbol{\%})\end{array}$ & $\begin{array}{l}\text { Fat } \\
(\boldsymbol{\%})\end{array}$ & $\begin{array}{l}\text { Crude } \\
\text { fiber }(\boldsymbol{\%})\end{array}$ & $\begin{array}{l}\text { Dietary } \\
\text { fiber }(\boldsymbol{\%})\end{array}$ & $\begin{array}{l}\text { Ash } \\
(\boldsymbol{\%})\end{array}$ \\
\hline Control & $\mathbf{4 . 8 0}$ & $\mathbf{7 . 2 4}$ & $\mathbf{6 0 . 7 1}$ & $\mathbf{2 5 . 8 9}$ & $\mathbf{0 . 6 2}$ & $\mathbf{0 . 3 0}$ & $\mathbf{0 . 7 4}$ \\
\hline $\mathrm{GCB}_{5}$ & 4.58 & 7.55 & 60.84 & 25.05 & 1.19 & 3.96 & 0.79 \\
\hline $\mathbf{G C B}_{\mathbf{1 0}}$ & $\mathbf{4 . 4 6}$ & $\mathbf{7 . 8 7}$ & $\mathbf{6 0 . 8 2}$ & $\mathbf{2 4 . 1 2}$ & $\mathbf{1 . 8 9}$ & $\mathbf{7 . 2 6}$ & $\mathbf{0 . 8 4}$ \\
\hline $\mathrm{GCB}_{15}$ & 4.30 & 8.19 & 60.82 & 23.18 & 2.62 & 10.92 & 0.89 \\
\hline $\mathrm{GCB}_{20}$ & 4.24 & 8.49 & 60.87 & 22.25 & 3.49 & 14.89 & 0.96 \\
\hline $\mathrm{SE} \pm$ & 0.037 & 0.008 & 0.013 & 0.016 & 0.005 & 0.017 & 0.012 \\
\hline $\mathrm{CD}$ at $5 \%$ & 0.11 & 0.024 & 0.039 & 0.050 & 0.01 & 0.05 & 0.037 \\
\hline
\end{tabular}

Where, $\mathrm{GCB}_{5}=5 \%$ bran, $\mathrm{GCB}_{10}=10 \%$ bran, $\mathrm{GCB}_{15}=15 \%$ bran and $\mathrm{GCB}_{20}=20 \%$ bran

Table.6 Influence of garden cress seed bran on micronutrient composition of cookies

\begin{tabular}{|l|c|c|c|c|}
\hline $\begin{array}{l}\text { Treatments } \\
\text { Control }\end{array}$ & $\begin{array}{c}\text { Calcium } \\
(\mathbf{m g} / \mathbf{1 0 0 g}) \\
\mathbf{2 6 . 1 2}\end{array}$ & $\begin{array}{c}\text { Phosphorous } \\
(\mathbf{m g} / \mathbf{1 0 0 g}) \\
\mathbf{1 1 1 . 0 3}\end{array}$ & $\begin{array}{c}\text { Iron } \\
(\mathbf{m g} / \mathbf{1 0 0 g}) \\
\mathbf{2 . 8 9}\end{array}$ & $\begin{array}{c}\text { Zinc } \\
(\mathbf{m g} / \mathbf{1 0 0 g}) \\
\mathbf{0 . 7 7}\end{array}$ \\
\hline $\mathrm{GCB}_{5}$ & 43.12 & 113.57 & 3.04 & 0.86 \\
\hline $\mathbf{G C B}_{\mathbf{1 0}}$ & $\mathbf{6 9 . 5 6}$ & $\mathbf{1 1 6 . 1 3}$ & $\mathbf{3 . 1 9}$ & $\mathbf{0 . 9 2}$ \\
\hline $\mathrm{GCB}_{15}$ & 92.14 & 119.68 & 3.34 & 0.97 \\
\hline $\mathrm{GCB}_{20}$ & 119.56 & 124.24 & 3.50 & 1.04 \\
\hline $\mathrm{SE} \pm$ & 0.013 & 0.013 & 0.048 & 0.012 \\
\hline $\mathrm{CD}$ at 5\% & 0.039 & 0.041 & 0.14 & 0.037 \\
\hline
\end{tabular}

Where, $\mathrm{GCB}_{5}=5 \%$ bran, $\mathrm{GCB}_{10}=10 \%$ bran, $\mathrm{GCB}_{15}=15 \%$ bran and $\mathrm{GCB}_{20}=20 \%$ bran 
Table.7 Textural characteristics of garden cress bran cookies

\begin{tabular}{|l|l|c|c|c|}
\hline $\begin{array}{l}\text { Sr. } \\
\text { No. }\end{array}$ & Treatments & $\begin{array}{c}\text { Crushing } \\
\text { force }(\mathbf{N})\end{array}$ & $\begin{array}{c}\text { Cutting } \\
\text { force (N) }\end{array}$ & $\begin{array}{c}\text { Penetration } \\
\text { force (N) }\end{array}$ \\
\hline 1 & Control & 50.51 & 35.28 & 13.82 \\
\hline 2 & $\mathrm{GCB}_{5}$ & 53.54 & 46.19 & 16.12 \\
\hline 3 & $\mathrm{GCB}_{10}$ & 83.55 & 50.18 & 17.26 \\
\hline 4 & $\mathrm{GCB}_{15}$ & 122.02 & 55.36 & 23.73 \\
\hline 5 & $\mathrm{GCB}_{20}$ & 137.74 & 59.58 & 27.21 \\
\hline 6 & $\mathrm{SE} \pm$ & 2.71 & 0.041 & 0.10 \\
\hline 7 & $\mathrm{CD}$ at $5 \%$ & 8.18 & 0.12 & 0.31 \\
\hline
\end{tabular}

Where, $\mathrm{GCB}_{5}=5 \%$ bran, $\mathrm{GCB}_{10}=10 \%$ bran, $\mathrm{GCB}_{15}=15 \%$ bran and $\mathrm{GCB}_{20}=20 \%$ bran

Influence of garden cress seed bran on nutritional quality of cookies

Proximate composition of garden cress seed bran fortified cookies

The proximate composition of cookies is presented in table 5. The cookies prepared with treatment $\mathrm{GCB}_{0} \quad(4.80 \%)$ was statistically superior in moisture content over other treatments followed by treatments $\mathrm{GCB}_{5}$ $(4.58 \%), \mathrm{GCB}_{10}(4.46 \%), \mathrm{GCB}_{15}(4.30 \%)$ and $\mathrm{GCB}_{20}(4.24 \%)$. The cookies with treatment $\mathrm{GCB}_{0}$ recorded highest fat percentage $(25.89 \%)$ whereas lowest $(22.25$ $\%$ ) fat was reported in treatment $\mathrm{GCB}_{20}$. The addition of bran slightly decreased the fat content of cookies. In cookies production, addition of fat imparts tenderness making it more palatable; assist in texture improvement. External added fat during preparation of cookies have plasticizing effects reported (Mulvancey and Cohen, 1997). Protein content of cookies in treatment $\mathrm{GCB}_{20}$ was highest $(8.49 \%)$ with lowest protein content in treatment $\mathrm{GCB}_{0}(7.24 \%)$. Treatment $\mathrm{GCB}_{20}(60.87 \%)$ was statistical superior in carbohydrates over all other treatments. Carbohydrates content of cookies with treatment $\mathrm{GCB}_{20}$ was highest $(60.87 \%)$ and lowest in control treatment $\mathrm{GCB}_{0}(60.71 \%)$. The ash content of cookies in treatment $\mathrm{GC} 22_{10}$ was highest $(0.96 \%)$ with lowest value in treatment $\mathrm{GCB}_{0}(0.74 \%)$.
The crude fiber and dietary fiber in cookies was 0.62 to 3.49 per cent and 0.30 to 14.89 per cent, respectively. Comparable results were reported by Nagarajaiah and Prakash, (2015) for dehydrated carrot pomace cookies. The use of oat bran, wheat bran, and rice bran as a source of dietary fiber content in bread and other bakery products was reported by Laurikainen et al., (1998) and Sidhu et al., (1999).

\section{Micronutrient composition of garden cress seed bran fortified cookies}

The prepared cookies with addition of different levels of garden cress seed bran were evaluated for calcium, phosphorous, iron, and zinc. The calcium, phosphorous, iron and zinc $(\mathrm{mg} / 100 \mathrm{~g})$ of cookies ranged from 26.12 $\left(\mathrm{GCB}_{0}\right)$ to $119.56\left(\mathrm{GCB}_{20}\right)$ (Table 6), 111.03 $\left(\mathrm{GCB}_{0}\right)$ to $124.24\left(\mathrm{GCB}_{20}\right), 2.89\left(\mathrm{GCB}_{0}\right)$ to $3.50\left(\mathrm{GCB}_{20}\right)$ and $0.77\left(\mathrm{GCB}_{0}\right)$ to 1.04 $\left(\mathrm{GCB}_{20}\right)$. The results showed that the calcium content of cookies was linearly increased as concentration of bran increases. There was significant variability of calcium, phosphorous, iron, and zinc content of prepared cookies than control sample. Clarke et al., (2003) reported pineapple pomace and wheat bran fortified biscuits also contains higher amount of calcium, phosphorus and iron Likewise Kuldip et al., (2014) also found the similar result. 
Influence of garden cress seed bran on textural quality of cookies

Texture is very important characteristic which makes a significant contribution to the overall acceptability of the food products. It is one of the three main acceptability factors used by consumers to evaluate food, the other two being appearance and flavour (Bourne, 2002). The average peak force is the measure of cookies hardness. Hardness was measured in terms of force required to crush the cookie or the force required to cut the cookie or the force required to penetrate the cookie. It was observed that there was significant increase in hardness of cookies with increased addition of garden cress seed bran.

The crushing force, cutting force and penetration force of garden cress seed bran incorporated cookies ranged from 50.51 (Control) to $137.74 \mathrm{~N}\left(\mathrm{GCB}_{20}\right), \quad 35.28$ (Control) to $59.58 \mathrm{~N}\left(\mathrm{GCB}_{20}\right)$ and 13.82 (Control) to $27.21 \mathrm{~N}\left(\mathrm{GCB}_{20}\right)$, respectively (Table 7). The crushing force, cutting force and penetration force increased with incremental addition of garden cress seed bran in cookies. Hoseney and Rogers (1994) reported that hardness of cookies was caused by the interaction of proteins and starch by hydrogen bonding. Similar results were observed by Singh et al., (1996); Barnwal et al., (2013) and Rajiv et al., (2012).

The garden cress seed bran being a good source dietary fiber and minerals can be explored as a novel functional food ingredient in bakery products where refined wheat flour is used.

\section{Acknowledgment}

Mr. Y. R. Deshmukh acknowledges the financial assistance in the form of national merit fellowship provided by University Grants Commission, New Delhi.

\section{References}

A.O.A.C., 1990. Official Methods of Analysis $15^{\text {th }}$ Edn, Association of Official Analytical Chemists, Washington D.C. pp. 777-796.

Amerine M. A., Pangborn R. M. and Roessler E. B., 1965. Principles of Sensory Evaluation of Food. Academic Press, New York, Pp. 549.

Barnwal, P., Kore, P. and Alka, S. 2013. Effect of partially de-oiled maize germ cake flour on physico-chemical and organoleptic properties of biscuits. J. Food Processing Technol. 4 (4): 1-4.

Bourne, M., 2002. Food Texture and Viscosity: Concept and Measurement. Academic. New York. pp 353-368.

Bryan, R.M., Shailesh N. S., Jill K., Winkler M., Steven F. V.and Roque L., 2009.Evangelista. Composition and physical properties of cress (Lepidium sativum L.) and field pennycress (Thlaspi arvense L.) oils, Indust Crops Prod, 30, 199-205.

Clarke, C.I., Schober, T.J., Angst, E. and Arendt, E.K. 2003. Use of response surface methodology to investigate the effects of processing conditions on sourdough wheat bread quality. Eur. Food Res. Technol. 217:23-33.

Desai, A.D., Kulkarni, S. S., Sahu, A. K., Ranveer, R. C. and Dandge, P. B. 2010. Effect of supplementation of malted finger millet flour on the nutritional and sensorial characteristics of cake. Adv. J. Food Sci. Technol. 2(1): 67-71.

Eissa, H.A., Hussein, A.S. and Mostafa, B.E. 2007. Rheological properties and quality evaluation of Egyptian balady bread and biscuits supplemented with flours of ungerminated and germinated Legume seeds or mushroom. Poland J. Food Nutr. Sci. 57(4): 487-496.

Gill, V., and MacLeod A. J., 1980. Studies on glucosinolate degradation in Lepidium sativum seed extracts, Phytochem, 19, 1369.

Gokavi, S.S., Malleshi N. G. and Guo M. 2004. Chemical Composition of Garden Cress (Lepidium sativum) seeds and its fractions and use of bran as a functional ingredient, Plant Foods Human Nutr, 59, 105-111. 
Hooda, S., and Jood, S. 2005. Organoleptic and nutritional evaluation of wheat biscuits supplemented with untreated and treated fenugreek flour. Food Chem. 90: 427-435.

Hosney, R.C., and Rogers, D. 1994. Mechanism of sugar functionality in cookies. In $\mathrm{H}$. Faridi (Ed.). The Science of Cookie and Cracker Production. London, UK: Chapman Hall. pp. 189-196.

Kiple, K.F., and Kriemhild C. O., 2000. The Cambridge World History of Food and Drink. (Cambridge University Press, Cambridge), 1765.

Kuldip Ade, Aditya Lal, and Akash Rathod. 2014. Development and quality evaluation of pineapple pomace and wheat bran fortified biscuits. Int. J. Res. Engg. Adv. Technol. 2(3):144-150.

Kulkarni, S.S., Desai, A. D., Ranveer, R. and Sahoo, A. K. 2012. Development of nutrient rich noodles by supplementation with malted ragi flour. Int. Food Res. J. 19(1): 309-313.

Laurikainen, T., Härkönen, H., Autio, K., and Poutanen, K. 1998. Effects of enzymes in fibre-enriched baking. J. Sci. Food Agril. 76:239-249.

Mabberley, D.J., 1993. The Plant Book: a Portable Dictionary of the Higher Plants, (Cambridge University Press, Cambridge, UK).

Maier, U.H., Heidrun, G. and Zenk, M.H. 1998. Seven imidazole alkaloids from Lepidium sativum. Phytochem. 49(6): 1791-1795.

Mulvancey, F.J., and Cohen, C. 1997. Effect of added fat on the rheological properties of wheat flour dough. Cereal Chem. 74: 30411.

Nagarajaiah, S., and Prakash J. 2015. Nutritional composition, acceptability, and shelf stability of carrot pomace-incorporated cookies with special reference to total and $\beta$-carotene retention. Cogent Food and Agriculture. 1: 106-114.

Panse, V.S., and Sukhatme, P.V. 1985. Statistical method for agricultural workers. Indian Council of Agricultural Research Publication. New Delhi. Pp. 167-174.

Rajiv, J., Indrani, D., Prabhasankar, P. and Rao, G. V. 2012. Rheology, fatty acid profile and storage characteristics of cookies as influenced by flax seed. J. Food Sci. Technol. 49 (5): 587-593.

Rangrej, V., Shah, V., Patel, J. and Ganorkar, P. M. 2015. Effect of shortening replacement with flaxseed oil on physical, sensory, fatty acid and storage characteristics of cookies. J. Food Sci. Technol. 52(6): 3694-3700.

Sidhu, J. S., Al-Hooti, S. N., and Al-Saqer, J. M. 1999. Effect of adding wheat bran and germ fractions on the chemical composition of high-fiber toast bread. Food Chem. 67: 365-371.

Singh, P., Singh, G., Srivastava, S. and Agarwal, P. 2005. Physiochemical characteristics of wheat and finger millet blends. J. Food Sci. Technol. 42: 340-343.

Singh, R., Singh, G. and Chauhan, G. S. 1996. Effect of incorporation of defatted soy flour on quality of biscuits. J. Food Sci. Technol. 33(4):355-357.

Sudha, M., Vetrimani, R. and Leelavathi, K. 2007. Influence of fibre from different cereals on the rheological characteristics of wheat flour dough and on biscuit quality. Food Chem. 100: 1365- 1370.

The wealth of India - A Dictionary of Indian raw materials and industrial products, council of scientific and industrial research, New Delhi. Vol. VI, 1962. 70-73.

Vratanina, D.L., and Zabik, M.E. 1978. Dietary fiber sources for baked products: bran in sugar-snap cookies. J. Food Sci. 43(5): 1590-1594.

\section{How to cite this article:}

Deshmukh, Y.R., S.S. Thorat and Mhalaskar, S.R. 2017. Influence of Garden Cress Seed (Lepidium Sativum L.) Bran on Quality Characteristics of Cookies. Int.J.Curr.Microbiol.App.Sci. 6(9): 586-593. doi: https://doi.org/10.20546/ijcmas.2017.609.071 